\title{
Unusual catchment runoff in a high alpine karst environment influenced by a complex geological setting (Northern Calcareous Alps, Tyrol, Austria)
}

\author{
Karl Krainer $^{1} \cdot$ Gerfried Winkler $^{2} \cdot$ Sabine Pernreiter ${ }^{1} \cdot$ Thomas Wagner $^{2}$ \\ Received: 25 March 2021 / Accepted: 30 August 2021 / Published online: 29 September 2021 \\ (C) The Author(s) 2021
}

\begin{abstract}
Garber Schlag (Q-GS) is one of the major springs of the Karwendel Mountains, Tyrol, Austria. This spring has a unique runoff pattern that is mainly controlled by the tectonic setting. The main aquifer is a moderately karstified and jointed limestone of the Wetterstein Formation that is underlain by nonkarstified limestone of the Reifling Formation, which acts as an aquitard. The aquifer and aquitard of the catchment of spring Q-GS form a large anticline that is bound by a major fault (aquitard) to the north. Discharge of this spring shows strong seasonal variations with three recharge origins, based on $\delta^{18} \mathrm{O}$ and electrical conductivity values. A clear seasonal trend is observed, caused by the continuously changing portions of water derived from snowmelt, rainfall and groundwater. At the onset of the snowmelt period in May, the discharge is composed mainly of groundwater. During the maximum snowmelt period, the water is dominantly composed of water derived from snowmelt and subordinately from rainfall. During July and August, water derived from snowmelt continuously decreases and water derived from rainfall increases. During September and October, the water released at the spring is mainly derived from groundwater and subordinately from rainfall. The distinct discharge plateau from August to December and the following recession until March is likely related to the large regional groundwater body in the fissured and moderately karstified aquifer of the Wetterstein Formation and the tectonic structures (anticline, major fault). Only a small portion of the water released at spring Q-GS is derived from permafrost.
\end{abstract}

Keywords Karst $\cdot$ Permafrost hydrology $\cdot$ Springs $\cdot$ Tectonics $\cdot$ Austria

\section{Introduction}

In Austria, the Northern Calcareous Alps (including the Karwendel Mountains), particularly the thick, partly karstified carbonate sedimentary rocks of Triassic age such as limestone of the Wetterstein and Dachstein formations, provide important reservoirs for drinking water, supplying large cities (e.g. Innsbruck, Salzburg, Vienna) and many small communities with high-quality drinking water (e.g. Benischke et al. 2016; Plan et al. 2009) — for example, the city of Vienna receives

Karl Krainer

Karl.Krainer@uibk.ac.at

1 Institute of Geology, University of Innsbruck, Innrain 52, A-6020 Innsbruck, Austria

2 Institute of Earth Sciences, NAWI Graz Geocenter, University of Graz, Heinrichstraße 26, A-8010 Graz, Austria almost all of its drinking water (approximately 450,000 $\mathrm{m}^{3} /$ day) from karst springs in the eastern part of the Northern Calcareous Alps. The Kläffer Spring (Hochschwab), with an average discharge of $5.4 \mathrm{~m}^{3} / \mathrm{s}$, provides about $60 \%$ of the drinking water supply of Vienna (Plan et al. 2010). About $25 \%$ of the world's population depends on karst aquifers for their water supply (e.g. Chen et al. 2017).

Hydrology of the Northern Calcareous Alps is mainly influenced by meteorologic conditions (particularly snowmelt and precipitation events; e.g. Lauber et al. 2014), rock type (karstified and jointed limestones, nonkarstified limestones, jointed dolomitic rocks, marls, shales, evaporitic rocks; e.g. Plan et al. 2009), tectonic structures (faults and folds, joints, e.g. De la Torre et al. 2020; Goldscheider 2005; Gremaud et al. 2009; Reischer et al. 2015) and debris cover (e.g. Lauber et al. 2014).

From the recently published rock glacier inventory of Austria (Wagner et al. 2020a), it is known that 500 from a total of 5,769 rock glaciers $(\sim 9 \%)$ were identified in karstifiable rocks. In particular, 212 are in the Northern 
Calcareous Alps in Tyrol covering an area of $10.8 \mathrm{~km}^{2}$, of which 46 are identified as intact indicating a permafrost impact on the headwaters and 166 as relict. Locally, in the Northern Calcareous Alps, permafrost ice is probably also present in north-facing talus slopes, although no data are available on the distribution of this type of permafrost in the Northern Calcareous Alps.

The importance of groundwater storage in alpine headwaters and its impact on downstream river systems was discussed in recent studies (e.g. Viviroli et al. 2020; Hayashi 2020). Many shallow alpine aquifers are related to periglacial and glacial landforms such as talus, moraines, rock glaciers, and meadows (Hayashi 2020) and may be affected by permafrost. In the last two decades an increasing number of field studies described and characterized these shallow alpine aquifers and their complexity (e.g. Clow et al. 2003; Winkler et al. 2016; Jones et al. 2018; Christensen et al. 2020). Hayashi (2020) showed their high storage capacity and therefore, their importance related to bedrock aquifers. Most of these alpine aquifers are located in areas built up by crystalline metamorphic rocks. Krainer et al. $(2010,2012)$ pointed out that the hydrology of rock glaciers in carbonate rocks differs significantly from that of metamorphic rocks. In catchments composed of carbonate rocks, most or all of the water of the rock glaciers is released along fissures or karst conduits and there is almost no surface discharge, although no data are available on how water derived from rock glaciers influences the discharge pattern of karst springs.

A lot of research has been undertaken during the last nearly 100 years to characterize karst spring runoff, summarized in many papers (e.g. Dewandel et al. 2003; Hergarten and Birk 2007; Carlotto and Chaffe 2019). However, very little is known about springs draining karstified areas with permafrost impact besides a recently published study related to the temperature pattern at karst springs in the Swiss Central Alps (Küry et al. 2017).

This report presents data on the complex discharge pattern of a large spring that drains a catchment composed of moderately karstified limestone (Middle Triassic Wetterstein Formation) in a high alpine environment. Alpine permafrost is present in the catchment in the form of a small intact rock glacier and probably also in the form of permafrost ice in the north-facing talus slopes at elevations above approximately 2,400 $\mathrm{m}$ above sea level.

The aim of this report is

- To discuss the complex hydrological setting concerning lithology and tectonic structures of the partly karstified rocks in the catchment, yielding a conceptual hydrogeological model

- To discuss the impact of alpine permafrost in the catchment on the discharge pattern of the studied spring

This is achieved by a combined approach using various hydrogeological methods, like continuous discharge measurements, recession analysis, isotopic analyses and tracer tests, and bringing the data into context with the geological setting.

\section{Materials and methods}

\section{Test site}

The Garber Schlag spring (Q-GS) is located at the bottom of a north-facing cirque called Marxenkar in the Karwendel Mountains (in the nature park "Alpenpark Karwendel") which is part of the Northern Calcareous Alps, approximately $15 \mathrm{~km}$ north of the city of Innsbruck (Fig. 1). In the upper part of the cirque, an active rock glacier is present at an elevation between approximately 2,280 and 2,420 m. In addition, another small rock glacier was mapped during fieldwork, which is not yet included in the current Austrian rock glacier inventory due to snow cover issues in the airborne laser scanning data.

\section{Geological setting}

The study area is located in the Karwendel Mountains which are part of the Northern Calcareous Alps and represent the sedimentary cover of the uppermost tectonic unit of the Austroalpine nappe system. Sedimentary rocks of the Northern Calcareous Alps range in age from the Permian to the Eocene (Mandl 2000).

The dominant rocks are different types of shallow marine carbonate sediments of Triassic age.

The Karwendel Mountains are composed of thrust sheets (Allgäu, Lechtal and Inntal thrust sheet from base to top) which internally display a complex tectonic structure (e.g. Heißel 1978; Eisbacher and Brandner 1995; Kilian and Ortner 2019). Rocks of the study area are part of the uppermost Inntal thrust sheet which is characterized by a large-scale E-W-trending fold and thrust architecture (Fig. 2). Anticlines are represented by mountain crests such as the Nordkette, Gleirsch-Halltal-Kette, Vomper Kette and Nördliche Karwendelkette, and synclines are represented by valleys such as the Gleirsch Valley, Hinterau Valley and Karwendel Valley (from $\mathrm{S}$ to $\mathrm{N}$ ). The Inntal thrust sheet is composed of mainly Triassic carbonate sediments.

Hydrogeology is controlled mainly by rock type and tectonic structures (Fig. 2). The main aquifers are the slightly karstified limestones of the middle Triassic Wetterstein Formation, subordinately the upper Triassic Hauptdolomit and middle Triassic Muschelkalk Group (particularly Virgloria and Steinalm formations).

A number of major springs with discharge $>100 \mathrm{~L} / \mathrm{s}$ occur in the Karwendel Mountains and are mainly released from rocks of the Inntal thrust sheet (Lechner et al. 2020). Only a few of these major springs are already used for drinking water 
Fig. 1 Location map of the study area in the Karwendel Mountains, Tyrol (Austria). Triangles indicate summits, black circles meteorologic stations (B Bodenwald, H Halltal Oberbergstollen, S InnsbruckSeegrube, K Kastenalm, T

Thaurer Alm)

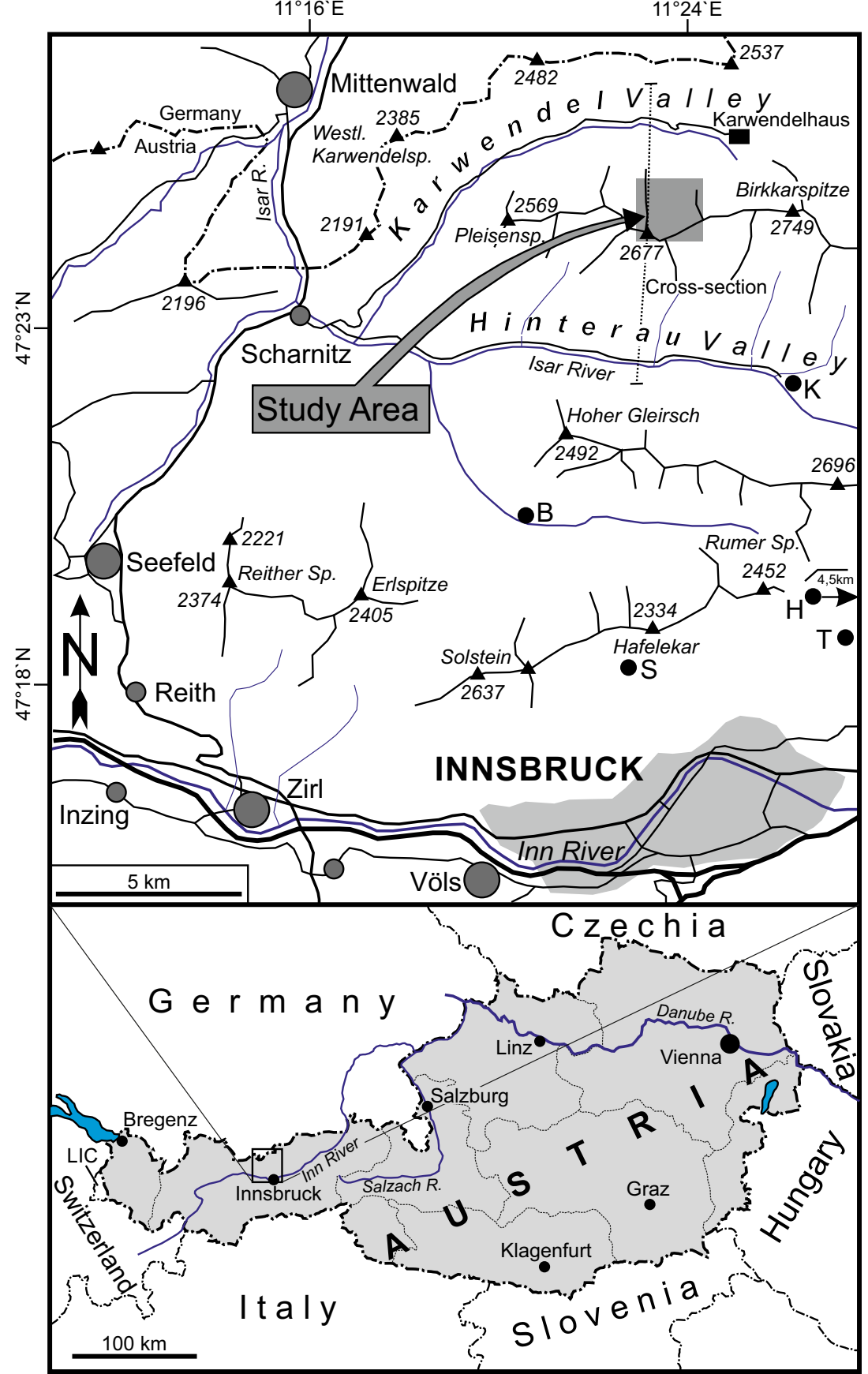

supply, such as the Mühlau springs that provide the bulk of the drinking water of the city of Innsbruck. Whereas the hydrogeology of the Mühlau springs (discharge 515-1,300 L/s; Lechner et al. 2020) is quite well studied (summarized in Heißel 1991, 1993), little is known about most of the major springs of the Karwendel Mountains such as the Q-GS.

Bedrock in the catchment of the Q-GS is entirely composed of limestone and subordinately of dolomite of the middle Triassic (Ladinian) Wetterstein Formation of the Inntal thrust sheet (Fig. 3). Most common in the study area is the bedded lagoonal facies of the Wetterstein Formation composed of subtidal, intertidal and supratidal deposits including peloidal packstones, limestone containing abundant dasycladacean algal fragments (Teutloporella herculanea) and stromatolites with LF-fabrics, desiccation cracks and tepee structures. Locally massive limestone representing the reef facies is developed. The thickness of the Wetterstein Formation ranges from 700 to 1,500 m (Brandner and Resch 1981; Nittel 2006; Pernreiter 2017).

In general, the western part of the Northern Calcareous Alps (including the Karwendel Mountains) is less intensively karstified compared to the central and eastern parts. The 


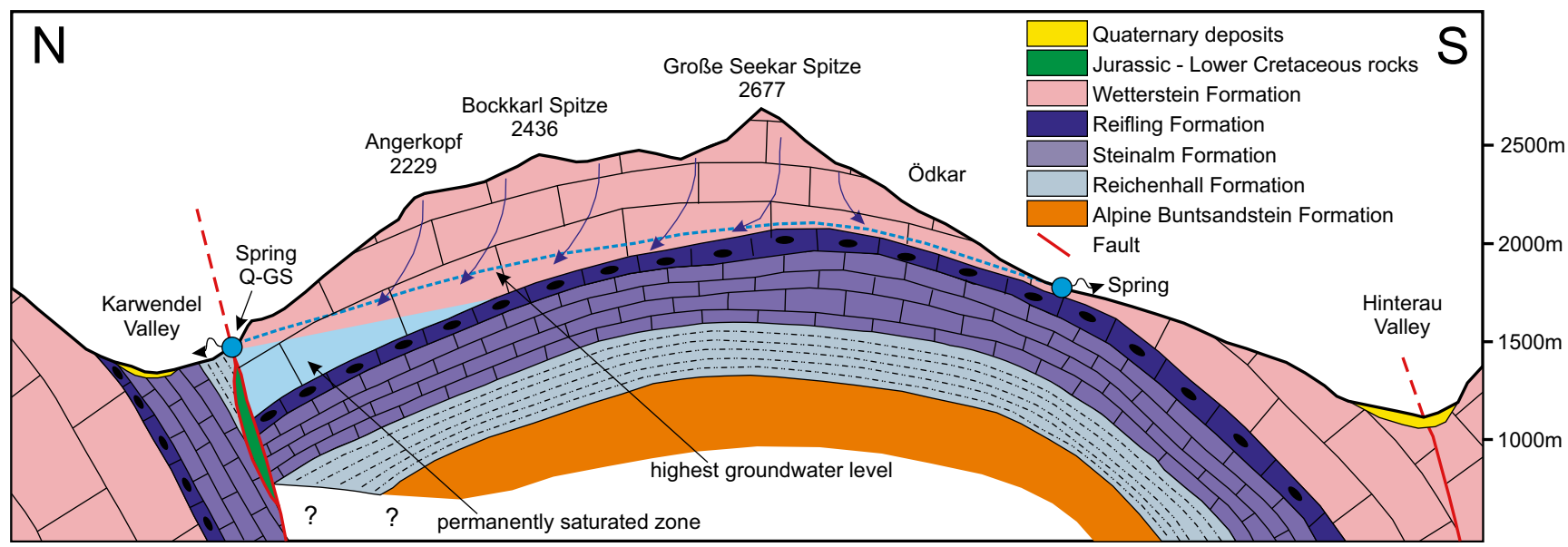

Fig. 2 Cross-section through the study area showing the tectonic structures (anticline, fault) and hydrogeological setting (after Heißel 1978, modified based on information from Alfred Gruber, GBA). The position of the cross-section is shown on Fig. 1

dominant karst host-rock in the Karwendel Mountains is limestone of the Wetterstein Formation (Spötl 2016). According to Spötl (2016), karstification in the Karwendel Mountains is low and surface karst features such as karren are rare. However, in the study area, the presence of karren (Fig. 4), dolines, shafts and small caves suggest the presence of a karst system within the limestone of the Wetterstein Formation. Karst caves occur near Pleisenspitze approximately $4 \mathrm{~km} \mathrm{~W}$ of Marxenkar (Fig. 1) and in the area of Bockkar approximately $8 \mathrm{~km}$ ESE of Marxenkar. Ice and sporadic perennial firn

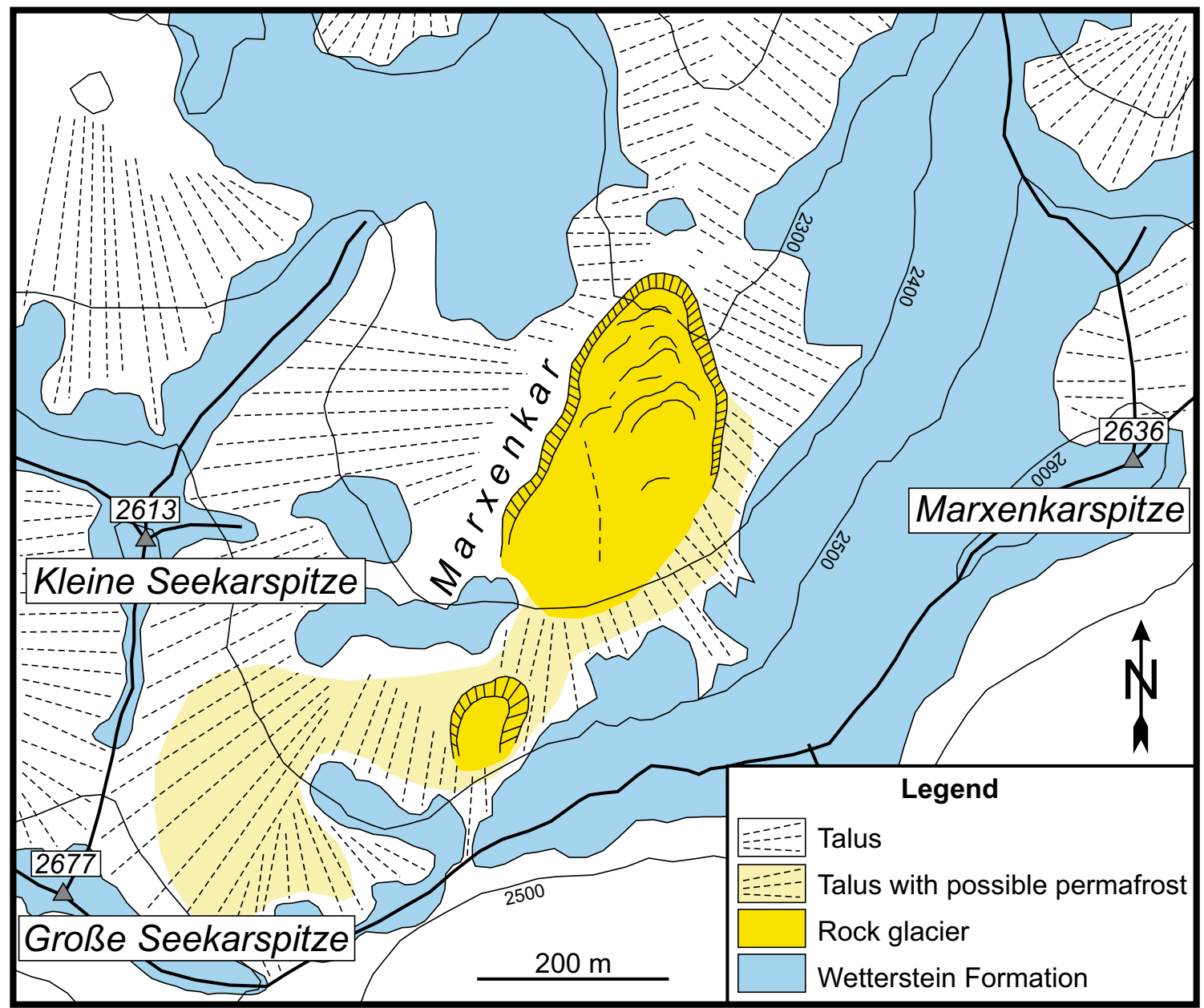

Fig. 3 Geologic-geomorphologic map of Marxenkar in the Karwendel Mountains with Marxenkar rock glacier 


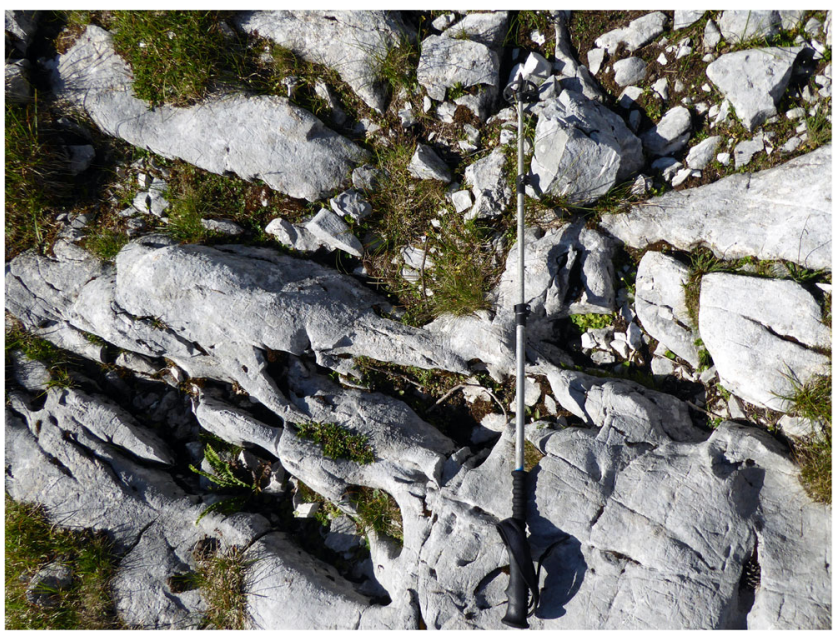

Fig. 4 Limestone of the Middle Triassic Wetterstein Formation at Marxenkar showing karst features (karren) at the surface (July 31, 2018)

deposits are observed in some of the high-alpine shafts in the Karwendel Mountains (Spötl 2016).

A prominent $\mathrm{E}-\mathrm{W}$-trending thrust fault is developed near the valley floor along which the Wetterstein Formation is tectonically underlain by the middle Triassic (lower Anisian) Reichenhall Formation which is composed of dark gray, thin-to-medium, even-to-wavy bedded muddy limestone containing crinoid fragments, ostracods and gastropods. The Reichenhall Formation is up to $500 \mathrm{~m}$ thick and also includes evaporitic carbonates (see Sarnthein 1966; Tollmann 1976; Pernreiter 2017). Along the thrust fault, tectonic breccias occur that are composed of clasts of the Wetterstein Formation embedded in a matrix of the Reichenhall Formation. Additionally, tectonic lenses of Jurassic to Lower Cretaceous rocks occur along this fault that was interpreted as a thrust fault at the base of the Inntal thrust sheet by Heißel (1978), but today is also interpreted as a major fault within the Inntal thrust sheet with a significant strike-slip component (Kilian and Ortner 2019). Wetterstein Formation and the subjacent units form a large-scale anticline towards the north in the investigation area.

\section{Springs}

The Garber Schlag spring (Q-GS; Figs. 5 and 6) is located at this prominent thrust fault, at the tectonic contact between the karstified limestone of the Wetterstein Formation and the underlying nonkarstified Reichenhall Formation and tectonic lenses of Jurassic to Lower Cretaceous rocks, which likely acts as an aquitard in regional scale (e.g. Ramspacher et al. 1992).

There is at least a moderate degree of karstification observable in the area and the location of the spring is in a rather elevated position related to "gullies" on either side. The western gully is usually dry and surface water flow is observed only during extreme storm events. The eastern gully is actually drained by another spring (Q-E). Discharge of this spring is also quite high although no data are available as the spring is difficult to access due to a rock cliff below. Importantly, this spring seems to drain the catchment in the east, as was determined from topographic delineations (see Fig. 5).

A small spring (spring Q1; Fig. 5) is located approximately $330 \mathrm{~m}$ below the front of the rock glacier at an elevation of $2,160 \mathrm{~m}$. This spring is located where the bedrock (limestone) is exposed on the surface and water is released at the boundary between the limestone and debris. The topographic catchment of the spring Q1 measures approximately $0.6 \mathrm{~km}^{2}$; the topographic catchment of the rock glacier is approximately $0.46 \mathrm{~km}^{2}$. Spring discharge could not be measured continuously, but during the melt season discharge reached its maximum of about $1 \mathrm{~L} / \mathrm{s}$ (Fig. 5). Compared to the catchment size, only a small part of the infiltrating water obviously is drained by Q1.

The vertical difference of Q-GS to the spring Q1 is $760 \mathrm{~m}$, and $880 \mathrm{~m}$ to the front of the rock glacier. The topographic catchment of the spring Q-GS is approximately $2.3 \mathrm{~km}^{2}$, if the gully west of the spring is included. Further drainage from the Seekarl is likely, but this might also drain towards the Bockkarl to the west (Fig. 5).

\section{Permafrost affected area and rock glacier}

Particularly in the upper part of the catchment area (Marxenkar) the bedrock is partly covered with talus deposits, one small intact rock glacier and one very small rock glacierlike landform. Permafrost is probably also present in the north-facing talus deposits above an elevation of approximately $2,300-2,400 \mathrm{~m}$. This is based on field observations.

The rock glacier at Marxenkar is about $398 \mathrm{~m}$ long, up to $206 \mathrm{~m}$ wide and covers an area of 5.85 ha (Figs. 3 and 7). It is a tongue-shaped rock glacier that extends from an elevation of $2,278 \mathrm{~m}$ (front) to $2,421 \mathrm{~m}$ (rooting zone) and is exposed towards the north. The rock glacier is entirely composed of debris derived from limestone of the Wetterstein Formation. Debris was provided by rockfall events from the steep walls south of the rooting zone composed of limestone of the Wetterstein Formation. The surface of the rock glacier displays a pronounced morphology of transverse ridges and furrows (Fig. 7). A depression is developed in the rooting zone. The front of the rock glacier shows a slope of $45^{\circ}$ and is free of vegetation. As mentioned previously, a spring $(\mathrm{Q} 1)$ is located approximately $330 \mathrm{~m}$ from the steep front. Talus deposits are widespread in the catchment area (covering about $48 \%$ of the total area with a suspected thickness of $>2 \mathrm{~m}$ ) and potentially have considerable estimated thicknesses up to 5-10 m).

\section{Methods}

A detailed geomorphologic and geological mapping of periglacial landforms, in particular of an active rock glacier, 
Fig. 5 Location map of Marxenkar with the rock glacier and possible permafrost area, location of springs Q 1, Q-GS, Q$\mathrm{E}$, the gaging station and their catchment areas and the thrust fault

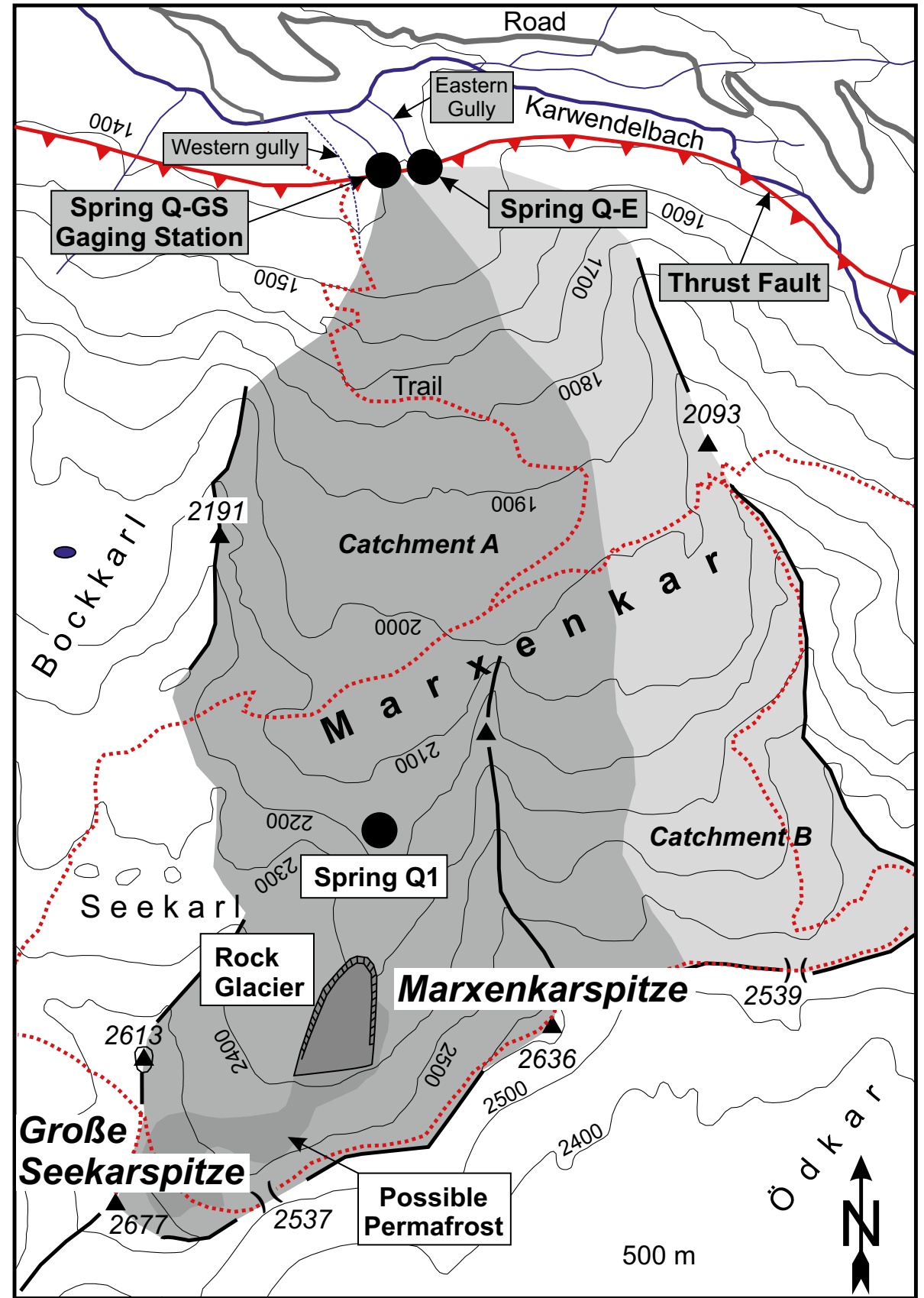

and the bedrock geology was carried out in a first step (Fig. 3). A temperature data logger was installed in the spring (Q 1) approximately $330 \mathrm{~m}$ downstream of the rock glacier front to record the water temperature during the melt season and summer. Additionally, a hand-held calibrated thermometer and electrical conductivity meter (WTW) was used for single measurements of water temperature and electrical conductivity.

A gaging station was installed at a distance of approximately $15 \mathrm{~m}$ from the spring Q-GS at which water level, electrical conductivity and water temperature were measured from Oct. 2015 until June 2017 at an interval of $1 \mathrm{~h}$ by using the data loggers "Gealog Micro" (Logotronic) and "MSD Dipper
PTEC" (SEBA). Gealog Micro (Logotronic) measured with an accuracy of $\pm 0.1 \%$ for the water level (height) and $\pm 0.2^{\circ} \mathrm{C}$ for the temperature. MSD Dipper PTEC (SEBA) measured with an accuracy of $\pm 0.1 \%$ for the water level, $\pm 1 \mu \mathrm{S} / \mathrm{cm}$ for the electrical conductivity and $\pm 0.1{ }^{\circ} \mathrm{C}$ for the temperature. The salt dilution method was used to determine the discharge at different water levels (Tracersystem TQ, SOMMER) to develop a rating curve for the gaging station. Flow dynamics and flow component separation of the spring discharge was performed with the master recession curves tool (MRCTools v3.1; Posavec et al. 2017) based on the exponential recession of a linear storage (Maillet 1905 in, e.g. Kresic 2007). 


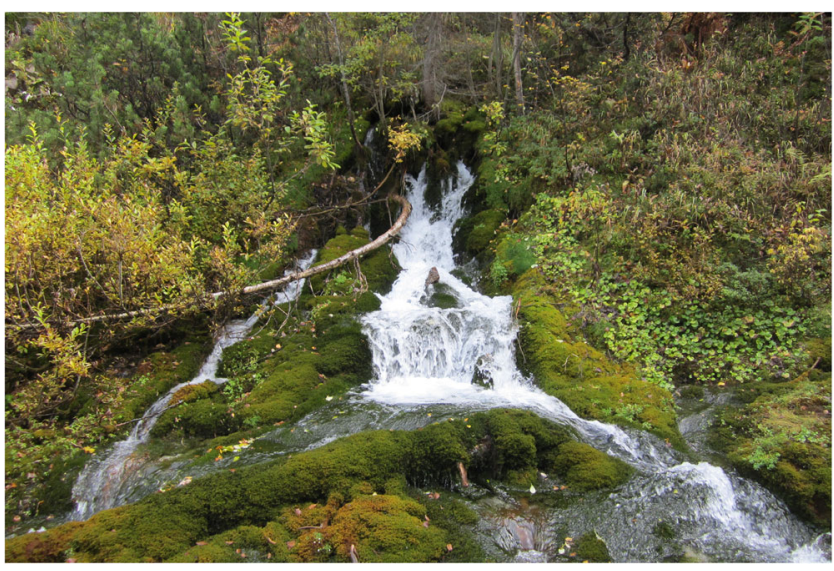

Fig. 6 Spring Q-GS located at an elevation of 1,400 m, 6 October 2015 (location see map Fig. 4)

Based on a catchment delineation using a digital elevation model with a $1 \times 1 \mathrm{~m}$ horizontal resolution, the topographic catchment area was estimated. Precipitation as potential maximum recharge was compared to measured discharge data at the Q-GS spring to decipher if, as often observed in karst catchments (e.g. Wagner et al. 2013), the actual subsurface catchment area is larger than the topographic catchment. Precipitation data of the investigated time period were provided from the surrounding official meteorologic stations Innsbruck-Seegrube 119,404, Thaurer Alm 197,079, Kastenalm 119,354, Bodenwald 119,362 and HalltalOberbergstollen 119,453 of the Hydrographic Service of Tyrol (Fig. 1). Based on the different elevations of these stations, a correlation between mean annual precipitation for the time period 2013 to 2017 and elevation was developed and applied for the mean elevation of the catchment $(2,174 \mathrm{~m}$ asl), thereby estimating a mean annual precipitation rate of the catchment. The measured discharge at Q-GS is about $81 \%$ of the precipitation input of the catchment yielding in an ET of about $20 \%$. Based on long-term data (1961-2010) from the

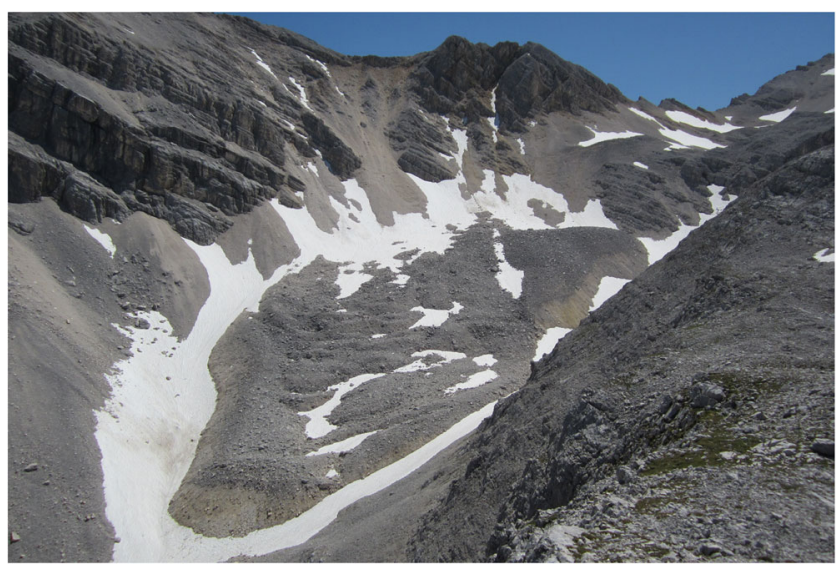

Fig. 7 View of the Marxenkar rock glacier with steep front and welldeveloped transverse furrows and ridges. View towards South (7 July 2015) data set SPARTACUS (Haslinger and Bartsch 2016; Hiebl and Frei 2016, 2018), ET seems to be approximately $30 \%$. All these values have to be considered as rough estimates as the measurement of discharge and the quantification of, in particular, solid precipitation in alpine regions is related to high uncertainties, and none of the surrounding official meteorologic stations are located at such high elevations as the mean catchment elevation $(1,230-1,921 \mathrm{~m}$ asl for the stations versus $2,174 \mathrm{~m}$ asl for the mean catchment elevation). However, it can be concluded that the recharge area and, in further consequence, the subsurface catchment of Q-GS seems to be slightly larger than the delineated orographic catchment.

Water samples for isotopic analyses have been collected at Q-GS between 20 May and 4 November 2016 with an automatic sampler, one sample per day with occasional interruptions. Additionally, collective samples from rainfall were taken at the gaging station of Q-GS in July (three samples), August (one sample), September (one sample), October (one sample) and November (one sample), and at the spring Q1 in July (two samples) and September (one sample).

The ratio of isotopes $\left({ }^{18} \mathrm{O} /{ }^{16} \mathrm{O},{ }^{2} \mathrm{H} /{ }^{1} \mathrm{H}\right)$ data have been compared to an international standard, in this case V-SMOW (Vienna Standard Mean Ocean Water). The O isotopic composition was determined by equilibration with carbon dioxide using an online continuous-flow system (Gasbench II) linked to a Finnigan DeltaplusXL mass spectrometer. Calibration of the mass spectrometer was accomplished using V-SMOW, GISP, and SLAP standards. The 1-sigma analytical error on the $\delta^{18} \mathrm{O}$ values is $0.09 \%$.

A dye tracer test was carried out on 14 September 2017 to test whether the water from the rock glacier at Marxenkar (spring Q1) appears at Q-GS or not. For the test, $155 \mathrm{~g}$ of fluorescein (uranine) were injected into the small stream released at Q1 (1 L/s discharge that day). The water of this stream reinfiltrates into the bedrock along a distance of about $50 \mathrm{~m}$. Water samples were collected automatically at an interval of $3 \mathrm{~h}$ during the first 3 days after injection and at $4 \mathrm{~h}$ during the following 4 days. These water samples were analysed with a Perkin Elmer (LS55B) fluorescence spectrometer on 18 October 2017 for the concentration of fluorescein (uranine).

\section{Results}

Discharge of the spring Q1 is low, mostly about $0.25 \mathrm{~L} / \mathrm{s}$ with peak discharge around $1 \mathrm{~L} / \mathrm{s}$ during the snowmelt season (based on various field visits only). During summer 2016, water temperature varied between 0.9 and $2.0{ }^{\circ} \mathrm{C}$, suggesting that the water is derived from permafrost-influenced debris/ talus and particularly from the active rock glacier. Electrical 
conductivity was $92 \mu \mathrm{S} / \mathrm{cm}$ on 10 July and $137 \mu \mathrm{S} / \mathrm{cm}$ at the end of July 2015.

Spring Q-GS is characterized by high discharge which shows pronounced seasonal variations and a discharge ratio $\left(Q_{\max } / Q_{\min }\right)$ larger than 20 (Fig. 8). Discharge measured on 6 Oct. and 4 Nov. 2016 was $100-104 \mathrm{~L} / \mathrm{s}$. As the spring is not accessible during winter because of snow avalanche danger, direct discharge measurements were not possible during this time period. Therefore, the uncertainty of the rating curve (water level-discharge relationship) at low water levels needs to be noted; however, water levels at the gaging station indicate that discharge decreases to values of $50 \mathrm{~L} / \mathrm{s}$ or less in late winter during base flow conditions (Fig. 8).

The highest discharge was directly measured on 16 June 2016 with 368-372 L/s. The highest peak was recorded on 17 June 2016 with a discharge of more than $500 \mathrm{~L} / \mathrm{s}$. Discharge data show an interesting seasonality. Low discharge can be observed from mid-November 2015 until the beginning of April 2016 with the lowest discharge recorded at the end of March. A strong increase of discharge occurred during April and May up to the values before the constant decrease between November 2015 and end of March 2016, interrupted by short periods of lower discharge probably caused by cool weather. Highest discharge was observed during the main snowmelt period from mid-May until about end-July, particularly during warm and sunny weather with intense snowmelt or during rainfall events (Fig. 8). From September to December 2016, discharge stays nearly constant with about $100 \mathrm{~L} / \mathrm{s}$ forming some kind of plateau with a slight increase in the last month up to about $110 \mathrm{~L} / \mathrm{s}$; it is interrupted by discharge peaks three times, indicating some rain events.

Particularly during the snowmelt period, pronounced daily runoff cycles were recorded in June 2016. The lowest discharge was recorded between 12:00 and 14:00 and peaks
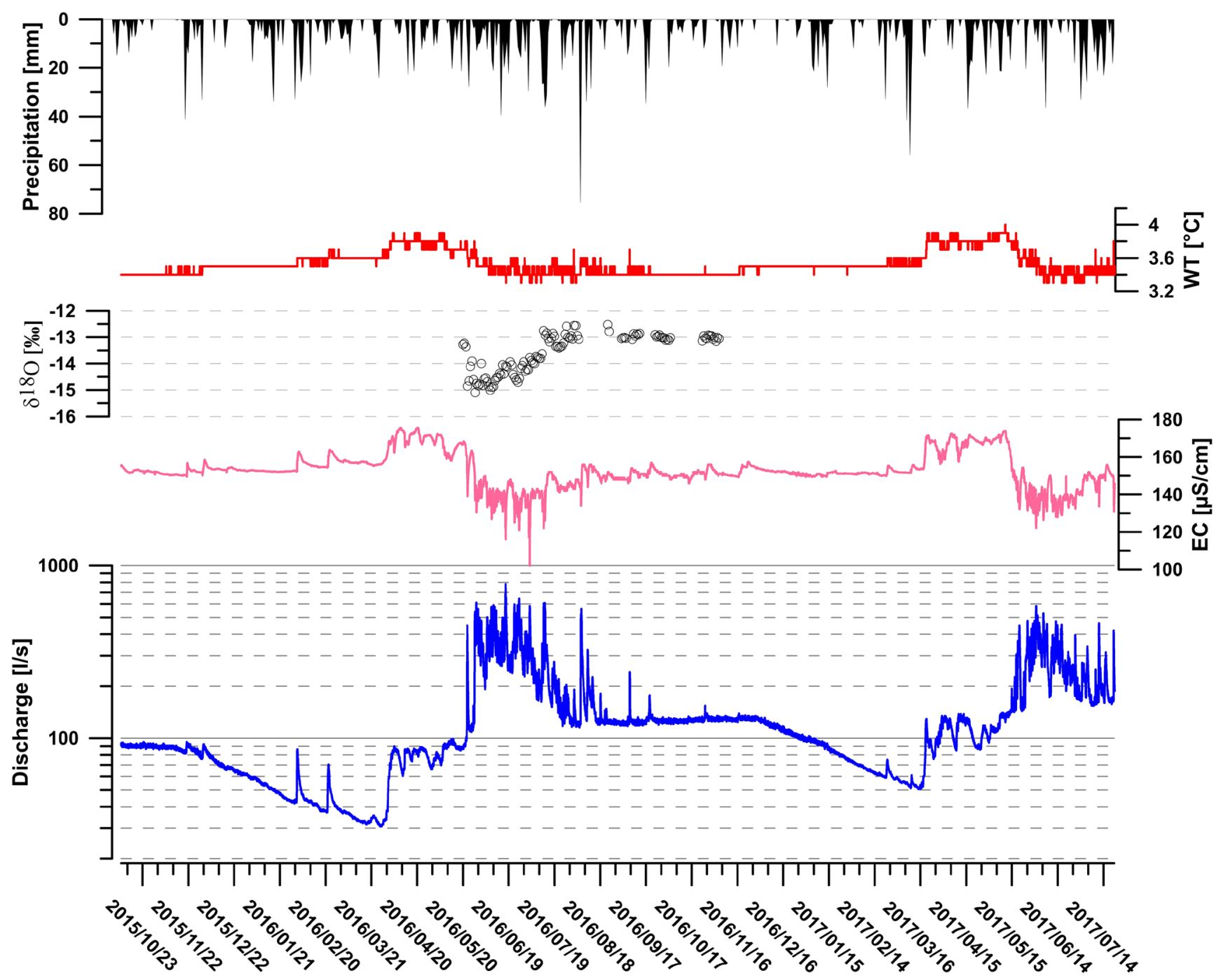

Fig. 8 a Hydrograph (blue line), electrical conductivity (pink line), water temperature (red line) of Spring Q-GS for the period October 2015July 2017; black bars indicate precipitation at the weather station
Innsbruck-Seegrube (S in Fig. 1); b discharge and EC time series of the spring; red arrows indicate a directly proportional correlation, green arrows indicate an inversely proportional correlation 
occurred in the late evening between 21:00 and 00:00. The range of these diurnal variations in runoff was mostly between 300 and $600 \mathrm{~L} / \mathrm{s}$ between lowest discharge and peak discharge (Fig. 8) and decreased strongly in July and August. The delay of the hydraulic response at the spring on snowmelt water infiltration is approximately $10 \mathrm{~h}$. The infiltration of low mineralized and cold snowmelt water is supported by diurnal variability of EC and water temperature (WT). The EC variability ranges between about 130 and $150 \mu \mathrm{S} / \mathrm{cm}$, and WT varies slightly with a range of about $0.1{ }^{\circ} \mathrm{C}$. The water temperature of the spring Q-GS ranges between 3.3 and $4.0^{\circ} \mathrm{C}$ (Fig. 8a), with the highest values between May and mid-June. The same trend was monitored in 2017 with a shift of about 14 days earlier.

Figure $8 \mathrm{~b}$ shows the time series of discharge $Q$ and EC and the correlation to each other. During the first snowmelt period from mid-April to end of July 2016, discharge and EC show an inversely proportional correlation with a decrease of EC simultaneously to an increase of discharge. After the snowmelt period starting at the end of July, the two parameters show a directly proportional behaviour till December. Each increase of discharge is accompanied with an increase of EC.
In this period the discharge is characterized by a plateau with some short-term peaks caused by precipitation events which do not cause a decrease in EC but hydraulically respond by an increase of discharge. In December, discharge shows a constant decrease till the beginning of the snowmelt period at end of March 2017. After a first increase period of EC and discharge up to $175 \mu \mathrm{S} / \mathrm{cm}$ and $100 \mathrm{~L} / \mathrm{s}$, respectively, till beginning of March, the two parameters behave inversely proportional.

During low discharge in autumn and winter, the electrical conductivity was between 145 and $155 \mu \mathrm{S} / \mathrm{cm}$, increasing slightly to values between 165 and $175 \mu \mathrm{S} / \mathrm{cm}$ at the beginning of the snowmelt period (March to mid-May 2016) probably because some of the water is stored in the phreatic zone. With the strong increase of discharge in mid-May 2016, the electrical conductivity decreased markedly, and during the snowmelt period values were mostly between 130 and $145 \mu \mathrm{S} / \mathrm{cm}$, but decreased down to $105 \mu \mathrm{S} / \mathrm{cm}$ during peak discharge. Figure 9 shows the recession coefficients of two winter periods with no groundwater recharge. Both coefficients are nearly identical, indicating the drainage of a single linear storage.

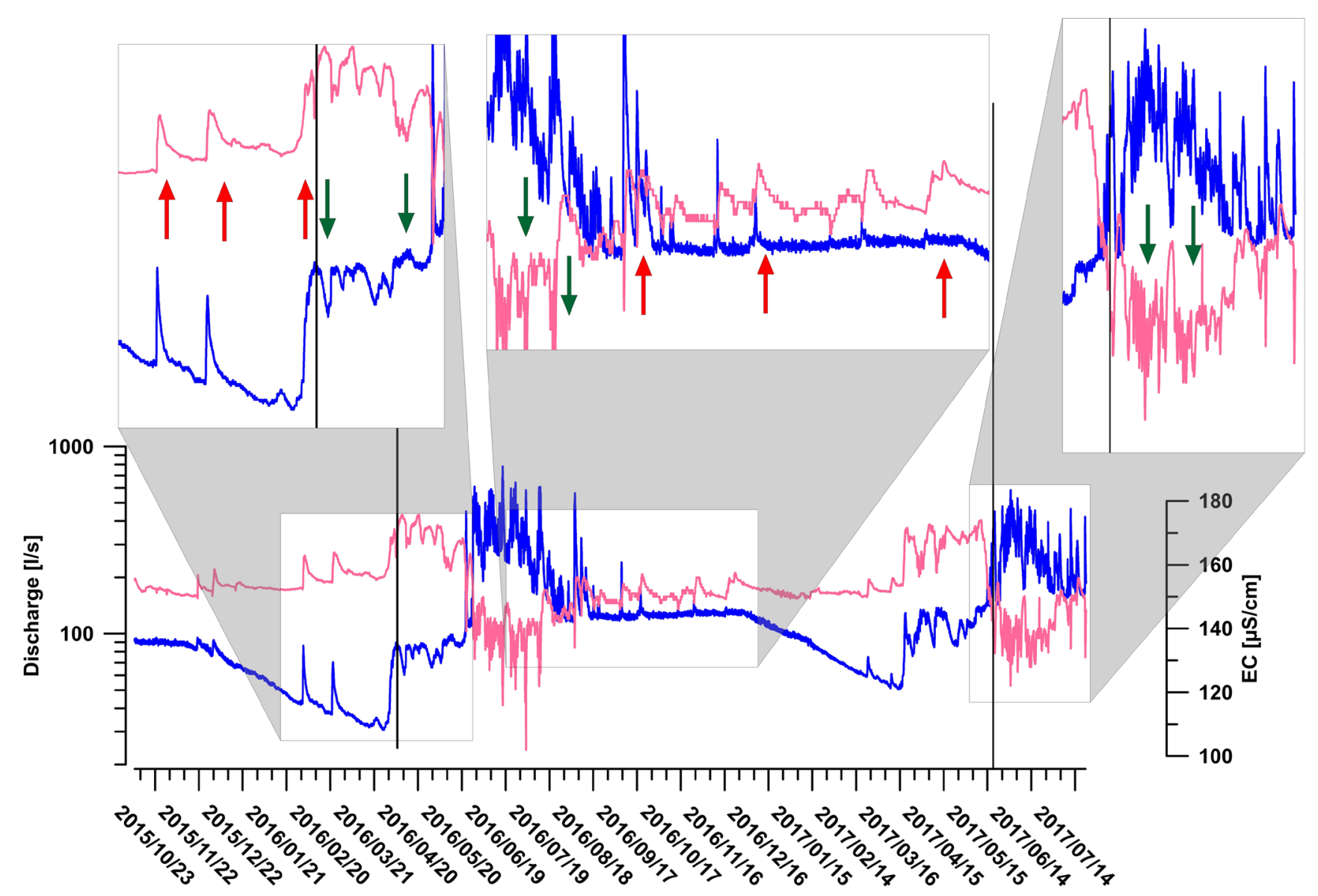

Fig. 8 (continued) 
In addition to the water samples that were collected by the automatic sampler at the spring Q-GS, water from rainfall was collected at the gaging station Q-GS and also at the spring Q1 ( $\delta^{18} \mathrm{O}$ values: mean $-9.81 \%$, SD $-2.07 \%$ ). The local meteoric water line (L-MWL) is based on all water samples collected at the spring Q-GS and rain samples $\left(\delta^{2} \mathrm{H}=7.52 \delta^{18} \mathrm{O}\right.$ + 6.62; Fig. 10).

The $\delta^{18} \mathrm{O}$ values of the rain water at the station Q-GS varied between -10.15 and $-6.26 \%$ in July $(-8.68$ and $-8.20 \%$ o at $\mathrm{Q} 1)$. In August $\delta^{18} \mathrm{O}$ values of the rain water were $-10.19 \%$, in September $-12.65 \%$ o $(-14.78 \%$ at Q1), in October $-11.28 \%$ and in November $-9.93 \%$.

As locations Q-GS and Q1 are not accessible during winter, it was not possible to collect snow samples for isotope analysis. In general, snow is enriched in light isotopes and the $\delta^{18} \mathrm{O}$ values of snow commonly range between -14 and $-17 \%$ at an elevation of approximately 2,300 $\mathrm{m}$ in the western Stubai Alps (Krainer et al. 2007). In the Schober Mountain Group near the Hochschoberhütte $(2,300 \mathrm{~m})$ and in front of the Bergli rock glacier in the Silvretta Mountain Group (2150 m), the snowpack yielded $\delta^{18} \mathrm{O}$ values ranging from -10 to $-21 \%$ o (mostly between $-14 \%$ and $-18 \%$ ) in March 2017 (Wagner et al. 2019).

When the $\delta^{18} \mathrm{O}$ values of the spring water Q-GS are plotted against the electrical conductivity, a clear seasonal trend is observed (Fig. 11): at the beginning of the snowmelt period in May the $\delta^{18} \mathrm{O}$ values decrease from -13 to $-15 \%$ and $\mathrm{EC}$ from 165 to $140 \mu \mathrm{S} / \mathrm{cm}$. In June, during the main snowmelt period, $\delta^{18} \mathrm{O}$ values are between -14 and $-15 \%$ and $\mathrm{EC}$ between 130 and $150 \mu \mathrm{S} / \mathrm{cm}$.

Fig. 9 Base flow recession of the two winter periods 2015-2016 and 2016-2017
In July $\delta^{18} \mathrm{O}$ values slightly increase to values between -13 and $-14 \%$ and EC is still low, between 130 and $150 \mu \mathrm{S} / \mathrm{cm}$. In August $\delta^{18} \mathrm{O}$ values slightly increase to values between -12.5 and $-13 \%$, and EC also increases to values of 145 $150 \mu \mathrm{S} / \mathrm{cm}$. During September and October, $\delta^{18} \mathrm{O}$ values are around $-13 \%$ and EC slightly increases to values of 150 $155 \mu \mathrm{S} / \mathrm{cm}$.

A similar seasonal trend was observed at the rock glacier spring of Bergli rock glacier in the Silvretta Moutain Group where the discharge of the rock glacier is derived from snowmelt, rainfall, ice melt and groundwater (Wagner et al. 2019).

The dominant impact of snowmelt seems to end at the end of June, since until the first of July, each recharge pulse responds as a depletion of heavier isotopes triggered by the snow signature. After the first of July, an increase of the heavier isotopes can be observed with each hydraulic pulse, indicating dominance of rainwater as the recharge component (Fig. 12).

For the artificial tracer test that was carried out in September 2017, fluorescein (155 g) was injected at spring Q1 at an elevation of 2,160 m on 14 September at 10:30. The small stream (with the tracer) infiltrated into joints of the Wetterstein limestone along a distance of approximately $50 \mathrm{~m}$.

The first appearance of the tracer at the spring Q-GS at an elevation of 1,400 $\mathrm{m}$ was recorded on 15 September, approximately $22 \mathrm{~h}$ after the injection of the tracer. The distance from the injection site to the spring Q-GS is approximately $1650 \mathrm{~m}$. This results in a maximum displacement velocity of $0.021 \mathrm{~m} / \mathrm{s}$. The first peak was recorded on 15 September,

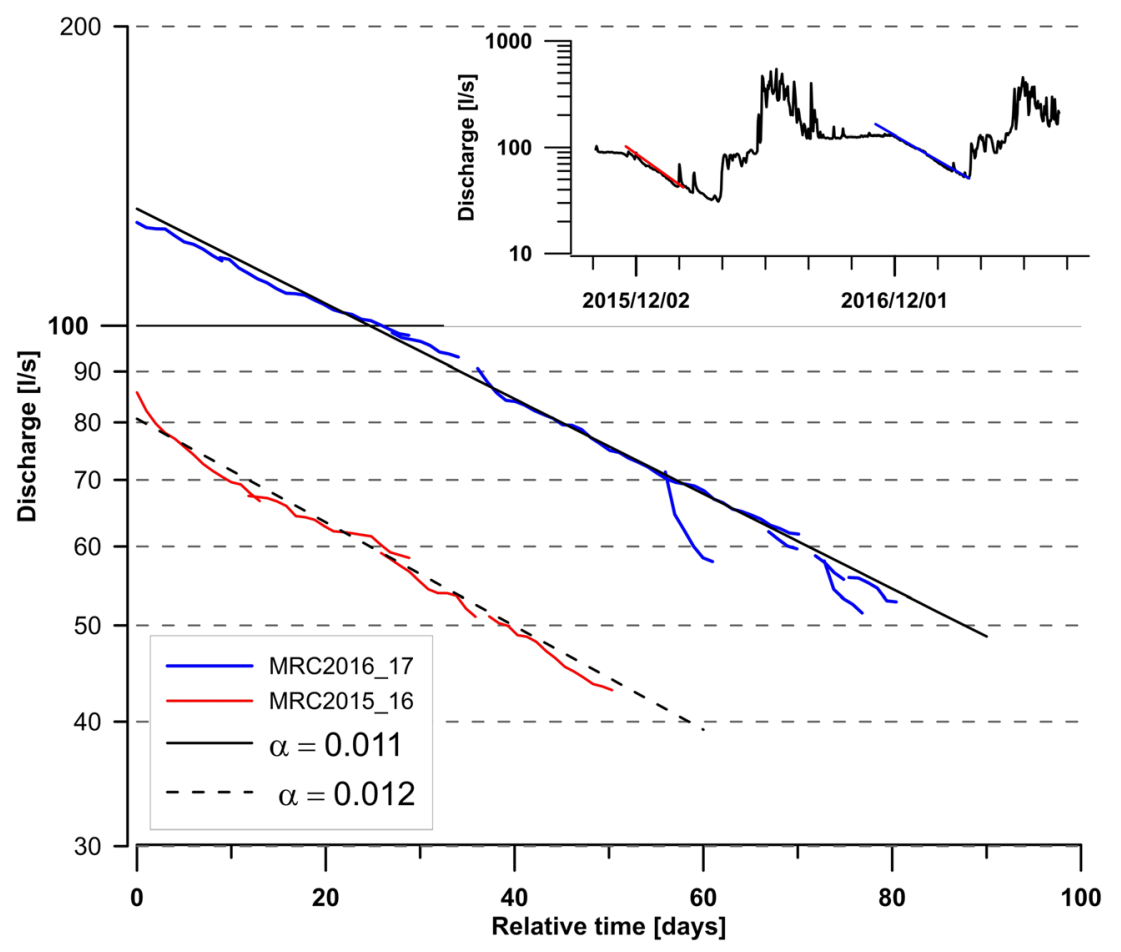




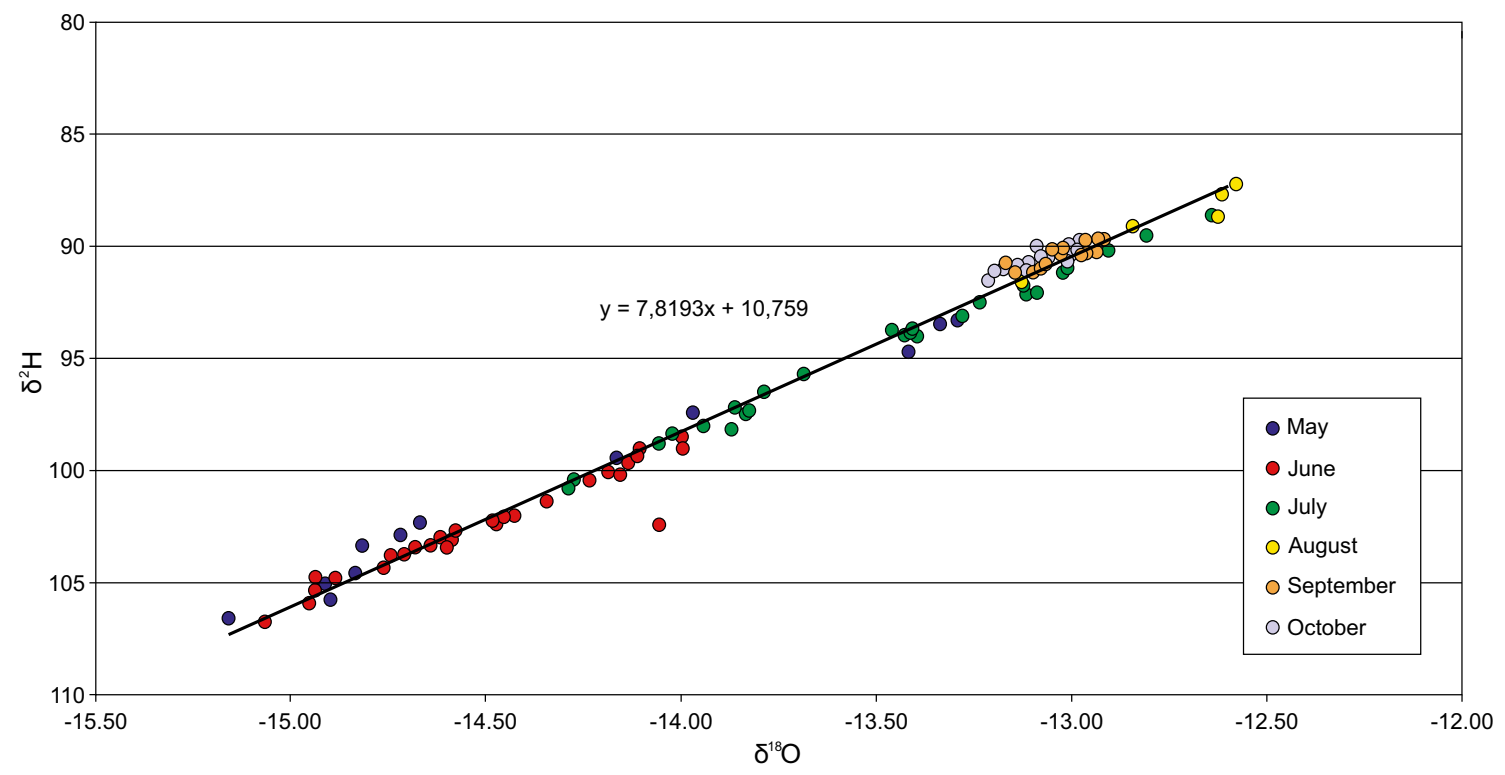

Fig. 10 Local meteoric water line for spring Q-GS based on oxygen isotope data of the period May till October 2017

around 14:00, approximately $27.5 \mathrm{~h}$ after the injection, resulting in a displacement velocity of $0.016 \mathrm{~m} / \mathrm{s}$. The last peak of the tracer occurred on 18 September, around $80.5 \mathrm{~h}$ after the injection resulting in a displacement velocity of $0.0057 \mathrm{~m} / \mathrm{s}$. No fluorescein was detected in the spring water after the last peak on 18 September (Fig. 13). Discharge remained constant during the entire period of the dye tracer test with discharge rates of about $100 \mathrm{~L} / \mathrm{s}$. Rainfall events and peaks in discharge were not recorded during this period. The recovery of the fluorescein is on the order of nearly $100 \%$ ( $5 \mathrm{ppb}$ with a discharge of $100 \mathrm{~L} / \mathrm{s}$ over 3.5 days yields $151.2 \mathrm{~g}$ ). No outflow via the western gully was observed.

\section{Discussion}

The spring data of Q-GS show a very interesting runoff pattern that indicates a complex hydrogeological system. Water released at the spring Q-GS is derived from three main sources: snowmelt, rainfall and groundwater. In general, these three types of water can be well distinguished when plotting the oxygen isotope values against the electrical conductivity - water derived from snowmelt is enriched in light isotopes (commonly -22 to $-15 \%$ ) and low values of electrical conductivity, whereas water derived from rainfall is also characterized by low values of electrical conductivity, but is enriched in heavy isotopes (mostly -8 to $-13 \%$ ). Both, water derived from snowmelt and rainfall suggest a fast flow component to the spring. Groundwater that forms the slowly moving component (baseflow) is characterized by high electrical conductivity and relatively constant $\delta^{18} \mathrm{O}$-values of around $-13 \%$ o due to longer residence times and a mixing process within the aquifer system.

The plot of $\delta^{18} \mathrm{O}$ against EC shows a clear seasonal trend that is caused by the continuously changing portions of water derived from snowmelt, rainfall and groundwater. At the onset of the snowmelt period in the beginning of May mainly groundwater is released (Fig. 12; high EC, $\delta^{18} \mathrm{O}$ around
Fig. 11 Oxygen isotope composition $\left(\delta^{18} \mathrm{O}\right.$ values $)$ versus electrical conductivity of spring Q-GS for the period May till October 2017

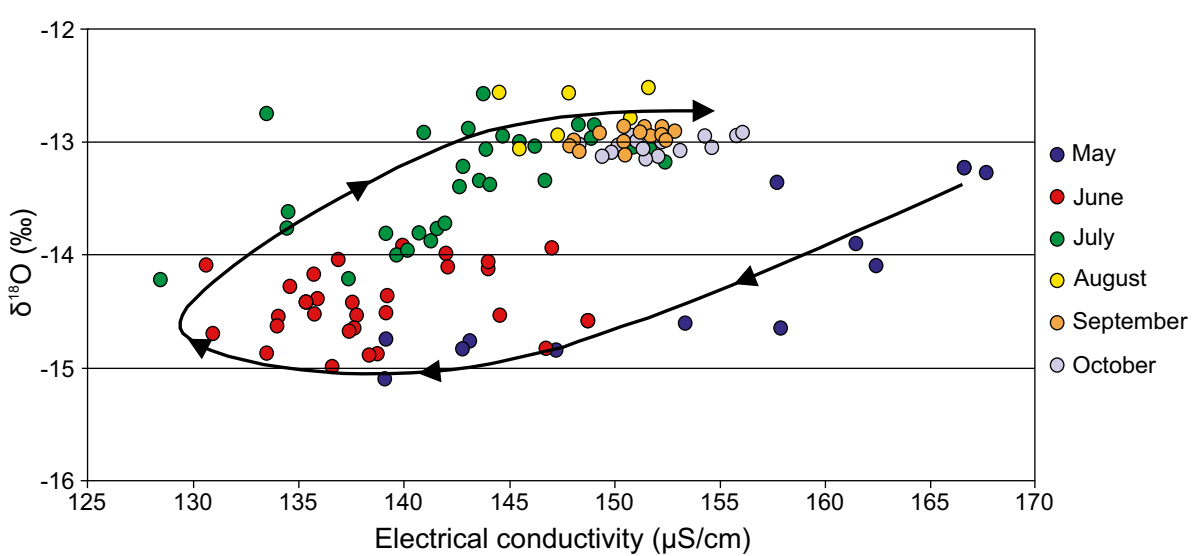




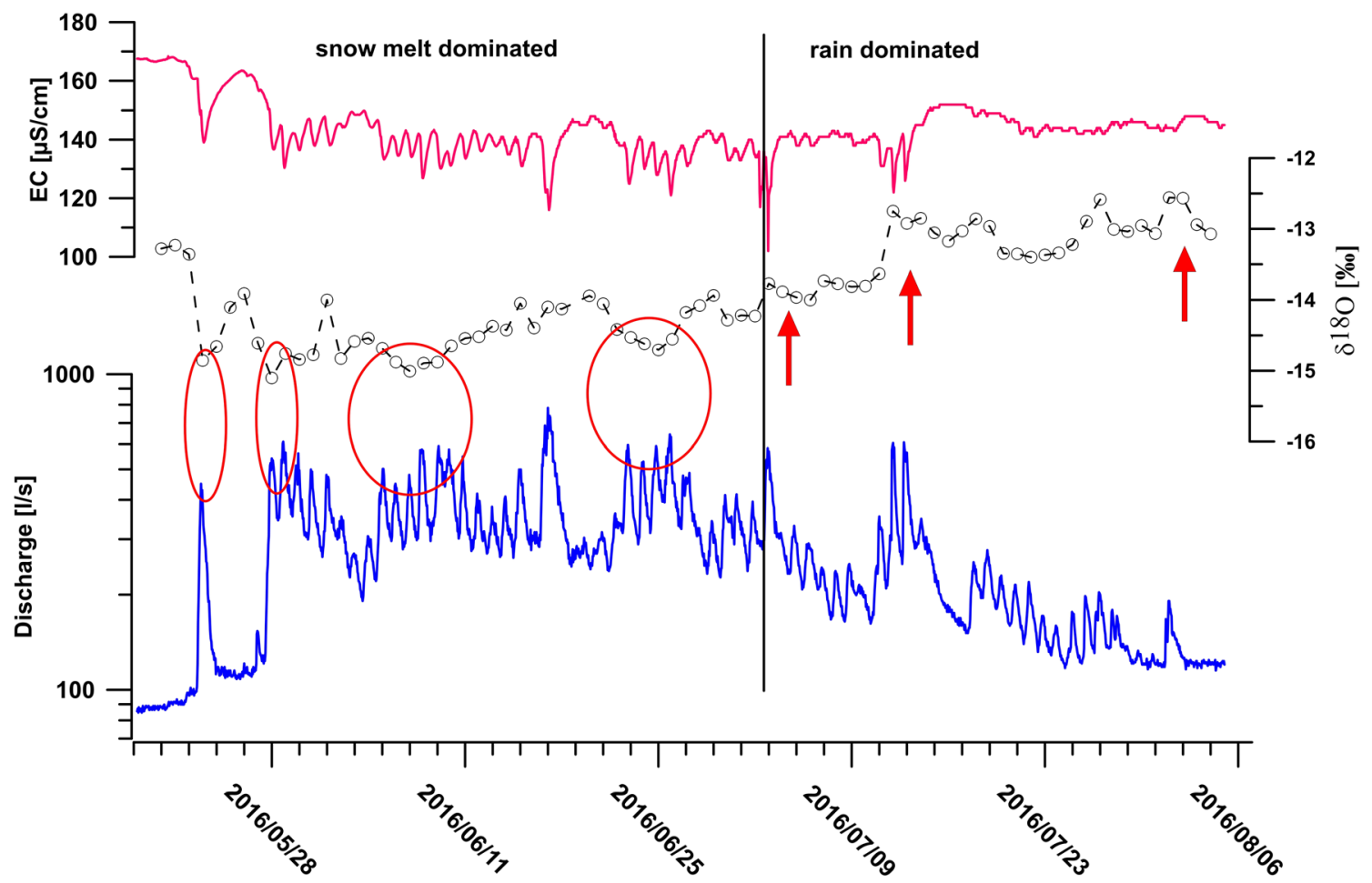

Fig. 12 Oxygen isotope composition ( $\left(\delta^{18} \mathrm{O}\right.$ values) of spring Q-GS for the period May till July 2016; red circles mark a depletion of heavier isotopes, red arrows mark an enrichment of heavier isotopes

$-13 \%$ ) which will be discussed in combination with the hydrograph analysis results later in the report. The increasing relative amount of snowmelt during May and June causes a significant increase in discharge, a decrease in EC to values of $130 \mu \mathrm{S} / \mathrm{cm}$ and a shift in $\delta^{18} \mathrm{O}$ to values around $-15 \%$ o during maximum snowmelt. At that time, water is dominantly derived from snowmelt and subordinately from rainfall events. The shift of EC from 130 to $150 \mu \mathrm{S} / \mathrm{cm}$ and of $\delta^{18} \mathrm{O}$ from -15 to $-11 \%$ o during July and August is caused by the continuous decrease of water derived from snowmelt and increase of water derived from rainfall. During July and August, discharge also decreases, indicating that the amount of groundwater most likely also increases, which might explain the increase in EC. During September and October, the water released at the spring is characterized by high values of EC (147$157 \mu \mathrm{S} / \mathrm{cm}$ ) and relatively stable values of $\delta^{18} \mathrm{O}$ of around $-13 \%$, indicating that the water is mainly derived from groundwater (higher mineralized) and subordinately from rainfall. The temporarily varying dominance of the three flow components rainfall, snowmelt and groundwater at the spring reflect a complex aquifer with different aquifer components.

The characteristic plateau of the discharge during August to December with the subsequent base flow recession until end of March and the extreme diurnal variability of discharge values during the snowmelt period suggest two different aquifer components with different hydraulic properties (Fig. 8). The direct and inverse correlation of EC vs. $Q$ over time supports the model of the two different aquifer components providing a temporarily varying dominance of the three flow components rainfall, snowmelt and groundwater at the spring.

One aquifer component is characterised by the plateau of the discharge values during the period August-December with the subsequent base flow recession until the end of March. This recession is interpreted as one linear storage with a constant recession coefficient of about $0.11 \mathrm{~L} /$ day (Fig. 9). The discharge share of this aquifer component to the total discharge of spring Q-GS seems to be limited to about 100$110 \mathrm{~L} / \mathrm{s}$ (Fig. 8). The increase of EC with increase of $Q$ during summer time (August-October) can be explained by a hydraulic pulse after precipitation events when older groundwater is pushed out following the idea of a piston flow model. The same model can be applied during March when the discharge reaches the threshold of about $100 \mathrm{~L} / \mathrm{s}$ again. This is consistent with the isotopic signature at that time; additionally, the snowmelt period can clearly be separated from the rainfall dominated period with the isotopic signature of the spring water at the beginning of July (see Fig. 12). Above this discharge threshold of about $100 \mathrm{~L} / \mathrm{s}$, probably during the snowmelt period and early summer till August, a second aquifer component seems to be active and dominating as EC and $Q$ become indirectly proportional (Fig. 8b). During the snowmelt period daily runoff cycles are recorded with lowest discharge between 12:00 and 14:00 and peak discharge in the late evening. The diurnal variability of $Q$ ranges between 250 and $600 \mathrm{~L} / \mathrm{s}$ with a hydraulic response shift to the most intense snowmelt in the early afternoon (around 15:00) of up to $10 \mathrm{~h}$. This high 


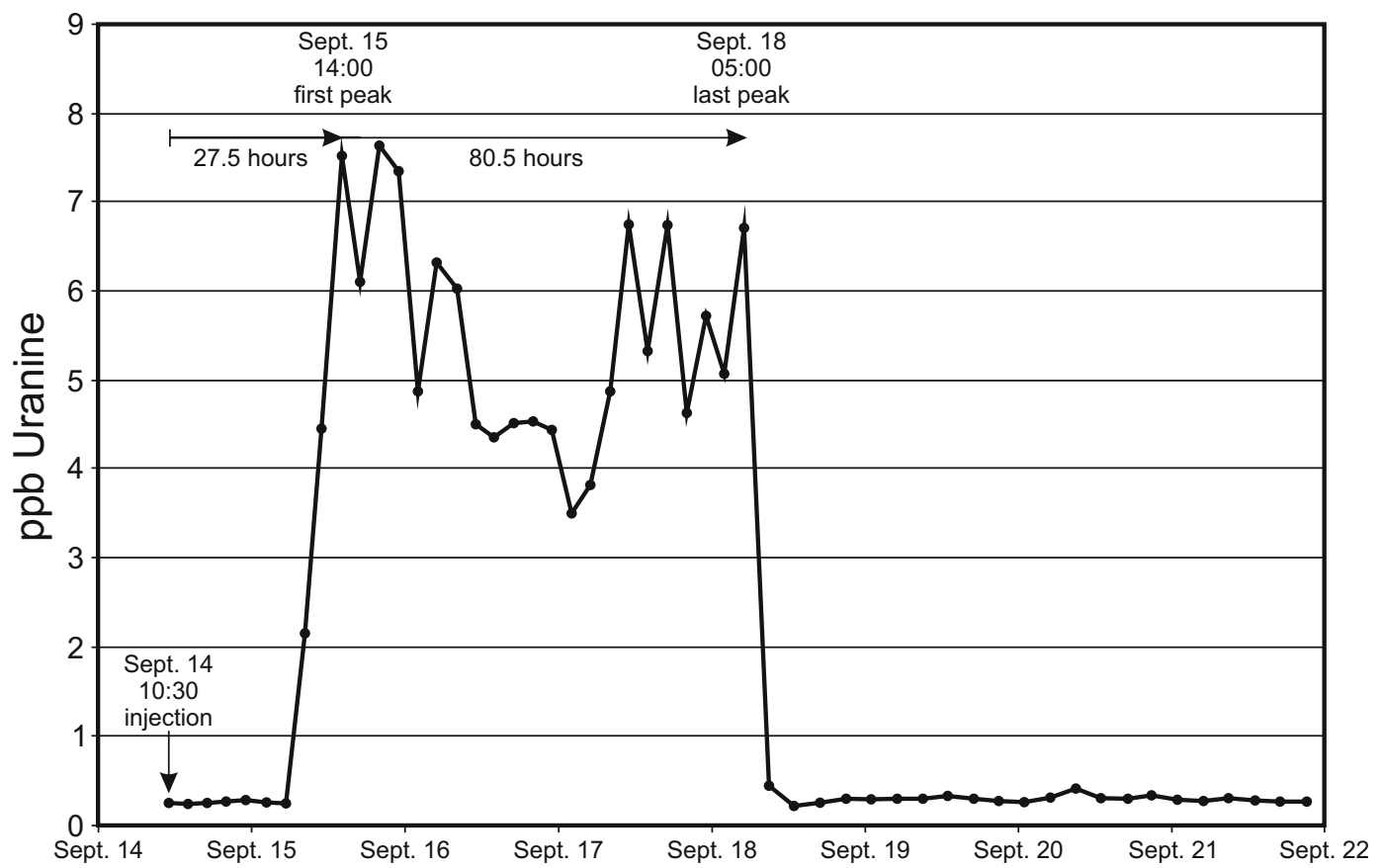

Fig. 13 Concentration of uranine (fluoresceine) detected at spring Q-GS after the injection at spring Q1

diurnal variability and delay indicate a large recharge area with a fast infiltration capability.

The diurnal EC variability is only about $15-20 \%$ of total EC contrary to the high discharge variability of $50-100 \%$ of total discharge. This again supports a high share of older groundwater pushed out of the system with a smaller portion of some fast flow component where low mineralized snowmelt water quickly reaches the spring.

This unusual runoff pattern can presumably be explained by a complex geological setting. The geological cross section in the area shows that the Wetterstein Formation and the underlying Reifling, Steinalm and Reichenhall formations form an anticline (Fig. 2). The Wetterstein Formation is considered to be the aquifer and the underlying Reifling Formation the aquitard at the base (e.g. Ramspacher et al. 1992). The main aquifer in the Wetterstein Formation seems to be moderately karstified (Ramspacher et al. 1992). On a regional scale, it can be observed that on the southern side of the mountain range, springs occur at an elevation of about $1,800 \mathrm{~m}$ asl, while in the north, Q-GS is located at an elevation of about 1,400 $\mathrm{m}$ asl This shows that the outflow level in the south is higher than in the north (Fig. 2). The anticlinal aquitard can act as a water divide in the subsurface when the water level decreases below the top of the aquitard, thereby the northern part is separated from the southern (Fig. 2). During periods of higher water level, the southern side seems to be drained towards the northern side with an overflow upper limit of about 100-110 L/s towards the north and the rest of the water drains towards the south. The discharge plateau at spring Q-GS can be related to this overflow above the top of the anticlinal aquitard with an upper limit of discharge at time periods with high water level in the system. When the water level decreases below the top of the anticlinal aquitard the northern part of this aquifer (Fig. 2) is separated and drains with a typical base flow recession till March (Fig. 9). At the end of March, the northern aquifer is replenished by the beginning snowmelt on the southern side of the mountain range till discharge reaches again a value of about $100 \mathrm{~L} / \mathrm{s}$.

During this time period, an increasing EC and $Q$ suggest hydraulic pulses thereby pushing out older groundwater. After this period, till May, a second flow component seems to be active, as EC and $Q$ are indirectly correlated. The massive snowmelt input of the Marxenkar (northern side) seems to occur in May and June, as the decreasing EC and increasing $Q$ (inversely proportional) can be explained by low-mineralized snowmelt water arriving at the spring. The existence of a moderately developed karst system in the catchment (Marxenkar) and a related fast flow component is demonstrated by the artificial tracer test that results in a travel time of a few hours for a distance of more than $1 \mathrm{~km}$. However, this flow component seems to play a minor role during summer, autumn and winter. The absolute values of EC have to be interpreted with caution as EC acts like a reactive tracer in karst systems (e.g. Birk et al. 2014; Kaminsky et al. 2021). However, the difference of the variability of EC and $Q$ suggests that the discharge is dominated by older groundwater and a piston effect where hydraulic impulses are transferred through the aquifer. The very low seasonal variation of the water temperature at the spring Q-GS 
supports the conceptual model of a large storage volume of the "fissured" karst aquifer.

Some of the characteristics of the spring Q-GS, such as the strong seasonal variation in discharge and electrical conductivity, are typical for karst springs. According to Benischke et al. (2016) a systematic classification of karst springs does not exist because bedrock geology, particularly the degree of deformation (jointing, faulting folding and fractures), annual precipitation in the catchment, karst processes and the degree of karstification, discharge and hydrochemistry, may vary considerably which makes it difficult to classify the spring Q-GS as a typical karst spring. In particular, for this spring the complex geologic setting seems to play a key role by affecting the runoff pattern of spring Q-GS (Fig. 2). The presence of typical karst features in the limestone of the study area and the tracer test results indicate a locally well-developed karst system in the limestone of the Wetterstein Formation. This karst system enables a fast infiltration of water into the subsurface during snowmelt periods and rainfall events, thereby initiating hydraulic pulses and pushing out mainly older longer-stored groundwater from the aquifer. However, a smaller portion of snowmelt or rainfall water flows through the karst conduits/system directly to the spring reaching it within only some hours of delay.

Although spring Q-GS can be regarded as a karst spring, based on its discharge ratio and the lithologies of the aquifer, the dominant impact on the runoff pattern of this unusual spring is related to the tectonic and geologic setting. The Wetterstein Formation is known as a fissured slightly karstified aquifer containing a huge regional groundwater body. The actual impact of permafrost within the catchment of spring Q-GS (especially the rock glacier) seems to be subordinate and no direct influence is noticeable. The rock glacier catchment and the permafrost affected area (talus slopes) are only a small part of the total actual contributing catchment (including temporal recharge from the southern side of the mountain range). Additionally, the permafrost-affected catchment is influenced by some local karstification. Thus, the shallow alpine aquifers such as rock glaciers and talus slopes may not be developed as known from crystalline catchments (e.g. Hayashi 2020; Wagner et al. 2020b). It is likely that infiltrating water percolates rapidly into the karstified bedrock and is no longer stored in the shallow aquifers.

\section{Conclusion}

The studied spring Q-GS, one of the major springs in the Karwendel Mountains, shows a very distinct runoff pattern that is mainly controlled by lithology and tectonic structures. The runoff pattern of the spring Q-GS shows some typical features of a karst spring such as its annual discharge ratio $(>20)$ and the correlation between EC and discharge yielding two flow components. The catchment contains some permafrost affected areas with potential shallow aquifers (rock glaciers and talus slopes) and a distinct developed karst system. Both environmental conditions can yield a discharge pattern of two flow components, a fast and a delayed one. Oxygen isotope and electrical conductivity data allow to distinguish three main sources of water Firstly, there is water derived from snowmelt which is characterized by enriched values of light oxygen isotopes and low values of electrical conductivity. Secondly, after the snowmelt peak (May, June), water released at the spring is increasingly derived from rainfall precipitation that is characterized by low electrical conductivity and is enriched in heavy oxygen isotopes; and thirdly, groundwater that has a relatively high electrical conductivity and shows constant $\delta^{18} \mathrm{O}$ values of $-13 \%$, which is the dominant water source during autumn and winter until the onset of the snowmelt period.

However, the main peculiarity of the runoff pattern of QGS is the discharge plateau and the following recession from August to March. It is likely related to a large regional groundwater body in a fissured and moderately karstified aquifer (limestone of the Wetterstein Formation). This large aquifer is underlain by rocks that act as an aquitard (Reifling Formation) and the entire succession forms a large anticline that is bound by a major fault to the north. Along this major fault, Jurassic to Lower Cretaceous rocks occur as thin lenses, forming a very low-permeability aquitard. These tectonic structures - the large anticline and the major fault-mainly control the discharge pattern of spring Q-GS.

Thus, the karst system and probably the permafrostaffected areas dominantly trigger the runoff pattern only during the snowmelt season. Spring Q-GS is bound on a groundwater body with a large recharge area and a recharge process which can be described by a piston flow model. This spring seems to be qualitatively and quantitively less sensitive to climate warming making it attractive for water resource management schemes.

Only a small portion of the water released at spring Q-GS is derived from the Marxenkar rock glacier and its catchment, which is demonstrated by the dye tracer test. However, water derived from the rock glacier and permafrost-affected talus has almost no impact on the discharge pattern and water temperature of spring Q-GS.

This example of an alpine spring clearly shows the possible complexity of aquifer systems due to tectonic and geologic settings and the challenges due to limited data. The hydrogeological conceptual model can only be developed by the combination of different hydrogeological methods, including hydrological and hydrochemical methods, with a profound geologic understanding.

Acknowledgements This work is part of the Masters thesis of Sabine Pernreiter. We are grateful to the Bezirkshauptmannschaft (district administration) Innsbruck for permission to drive into the Karwendel 
Valley. We thank Alfred Gruber and Thomas Pedevilla for assistance in the field. We thank two anonymous reviewers for their comments and suggestions, which helped to improve the manuscript.

Funding Open access funding provided by University of Innsbruck and Medical University of Innsbruck. This study was funded by the Ministry of Sustainability and Tourism and the federal governments of Carinthia, Salzburg, Styria, Tyrol and Vorarlberg (DaFNE-Project 101093).

\section{Declarations}

Conflict of interests On behalf of all authors, the corresponding author states that there is no conflict of interest.

Open Access This article is licensed under a Creative Commons Attribution 4.0 International License, which permits use, sharing, adaptation, distribution and reproduction in any medium or format, as long as you give appropriate credit to the original author(s) and the source, provide a link to the Creative Commons licence, and indicate if changes were made. The images or other third party material in this article are included in the article's Creative Commons licence, unless indicated otherwise in a credit line to the material. If material is not included in the article's Creative Commons licence and your intended use is not permitted by statutory regulation or exceeds the permitted use, you will need to obtain permission directly from the copyright holder. To view a copy of this licence, visit http://creativecommons.org/licenses/by/4.0/.

\section{References}

Benischke R, Stadler H, Völkl G (2016) Karstquellen. In: Spötl C, Plan L, Christian E (eds) Höhlen und Karst in Österreich [Caves and karst in Austria]. Oberösterreichisches Landesmuseum, Linz, Austria, pp 73-96

Birk S, Wagner T, Mayaud C (2014) Threshold behavior of karst aquifers: the example of the Lurbach karst system (Austria). Environ Earth Sci 72:1349-1356. https://doi.org/10.1007/s12665-0143122-z

Brandner R, Resch W (1981) Reef development in the middle Triassic (Ladinian and Cordevolian) of the northern limestone Alps near Innsbruck, Austria. SEPM Spec Publ. 30, SEPM, Tulsa, OK, pp 203-231

Carlotto T, Chaffe PIB C (2019) Master recession curve parameterization tool (MRCPtool): different approaches to recession curve analysis. Comput Geosci 132:1-8. https://doi.org/10.1016/j.cageo.2019.06. 016

Chen Z, Auler AS, Bakalowicz M, Drew D et al (2017) The world karst aquifer mapping project: concept, mapping procedure and map of Europe. Hydrogeol J 25:771-785. https://doi.org/10.1007/s10040016-1519-3

Christensen CW, Hayashi M, Bentley LR (2020) Hydrogeological characterization of an alpine aquifer system in the Canadian Rocky Mountains. Hydrogeol J 28:1871-1890. https://doi.org/10.1007/ s10040-020-02153-7

Clow DW, Schrott L, Wobb R, Campell DH, Torizzo A, Dornblaser M (2003) Ground water occurrence and contributions to streamflow in an alpine catchment, Colorado Front Range. Groundwater 41:937950. https://doi.org/10.1111/j.1745-6584.2003.tb02436.x

Dewandel B, Lachassagne P, Bakalowicz M, Weng P, Al-Malki A (2003) Evaluation of aquifer thickness by analyzing recession hydrographs: application to the Oman ophiolite hard-rock aquifer. J Hydrol 274: 248-269
De la Torre B, Mudarra M, Andreo B (2020) Investigating karst aquifers in tectonically complex alpine areas coupling geological and hydrogeological methods. J Hydrol 6:100047. https://doi.org/10. 1016/j.hydroa.2019.100047

Eisbacher G, Brandner R (1995) Role of high-angle faults during heteroaxial contraction, Inntal thrust sheet, Northern Calcareous Alps, western Austria. Geologisch-Paläontol Mitteil Innsbruck 20: 389-406

Goldscheider N (2005) Fold structure and underground drainage pattern in the alpine karst system Hochifen-Gottesacker. Eclogae Geol Helv 98:1-17. https://doi.org/10.1007/s00015-005-1143z

Gremaud V, Goldscheider N, Savoy L, Favre G, Masson H (2009) Geological structure, recharge processes and underground drainage of a glacierised karst aquifer system, Tsanfleuron-Sanetsch, Swiss Alps. Hydrogeol J 17:1833-1848. https://doi.org/10.1007/s10040009-0485-4

Haslinger K, Bartsch A (2016) Creating long-term gridded fields of reference evapotranspiration in Alpine terrain based on a recalibrated Hargreaves method. Hydrol Earth Syst Sci 20(3):1211-1223. https://doi.org/10.5194/hess-20-1211-2016

Hayashi M (2020) Alpine hydrogeology: the critical role of groundwater in sourcing the headwaters of the world. Groundwater 58(4):498 510. https://doi.org/10.1111/gwat.12965

Heißel G (1978) Karwendel: geologischer Bau und Versuch einer tektonischen Rückformung [Karwendel - geological structure and attempt of a tectonic reshaping]. Geolog-Paläontol Mitteil Innsbruck 8:227-288

Heißel G (1991) Die Abhängigkeit der hydrogeologischen von den geologisch-tektonischen Verhältnissen des Karwendelgebirges, aufgezeigt am Beispiel der Mühlauer Quellen (Tirol, Österreich) [The dependence of the hydrogeological on the geological-tectonic conditions of the Karwendel Mountains, shown by the Mühlau springs (Tyrol, Austria)]. Tiroler Landesmuseum Ferdinandeum $71: 17-81$

Heißel G (1993) Die Hydrogeologie der Mühlauer Quellen im Lichte geologischer und strukturgeologischer Erkenntnisse unter Einbeziehung besonderer Aspekte der Geologie Tirols [The hydrogeology of the Mühlau springs in the light of geological and structural data, including special aspects of the geology of Tyrol]. Landesgeol Tirol 1:1-44

Hergarten S, Birk S (2007) A fractal approach to the recession of spring hydrographs. Geophys Res Lett 34:L11401. https://doi.org/10.1029/ 2007GL030097

Hiebl J, Frei C (2016) Daily temperature grids for Austria since 1961: concept, creation and applicability. Theor Appl Climatol 124(1-2): 161-178. https://doi.org/10.1007/s00704-015-1411-4

Hiebl J, Frei C (2018) Daily precipitation grids for Austria since 1961: development and evaluation of a spatial dataset for hydroclimatic monitoring and modelling. Theor Appl Climatol 132(1-2):327-345. https://doi.org/10.1007/s00704-017-2093-x

Jones DB, Harrison S, Anderson K, Betts RA (2018) Mountain rock glaciers contain globally significant water stores. Sci Rep 8:2834. https://doi.org/10.1038/s41598-018-21244-w

Kaminsky E, Plan L, Wagner T, Funk B, Oberender P (2021) Flow dynamics in a vadose shaft: a case study from the Hochschwab karst massif (Northern Calcareous Alps, Austria). Int J Speleol 50(2): 157-172. https://doi.org/10.5038/1827-806X.50.2.2375

Kilian S, Ortner H (2019) Structural evidence of in-sequence and out-ofsequence thrusting in the Karwendel mountains and the tectonic subdivision of the western Northern Calcareous Alps. Austrian J Earth Sci 112:62-83. https://doi.org/10.17738/ajes.2019.0005

Krainer K, Mostler W, Spötl C (2007) Discharge from active rock glaciers, Austrian Alps: a stable isotope approach. Austr J Earth Sci 100:102-112 
Krainer K, Lang K, Hausmann H (2010) Active rock glaciers at Croda Rossa/Hohe Gaisl, eastern Dolomites (Alto Adige/South Tyrol, northern Italy). Geogr Fis Dinam Quat 33:25-36

Krainer K, Mussner L, Behm M, Hausmann H (2012) Multi-disciplinary investigation of an active rock glacier in the Sella group (Dolomites; northern Italy). Austr J Earth Sci 105:48-62

Kresic N (2007) Hydrogeology and groundwater modeling, 2nd edn. CRC, Boca Raton, FL

Küry D, Lubini V, Stucki P (2017) Temperature patterns and factors governing thermal response in high elevation springs of the Swiss Central Alps. Hydrobiologia 793:185-197. https://doi.org/10.1007/ s10750-016-2918-0

Lauber U, Kotyla P, Morche D, Goldscheider N (2014) Hydrogeology of an Alpine rockfall aquifer system and its role in flood attenuation and maintaining baseflow. Hydrol Earth Syst Sci 18:4437-4452. https://doi.org/10.5194/hess-18-4437-2014

Lechner K, Ribis M, Poscher G (2020) Großquellen der Kluft- und Karstgrundwasserleiter im Karwendel (Nördliche Kalkalpen, Tirol) [High-discharge springs of the Karwendel Massif (Northern Limestone Alps, Tyrol)]. Grundwasser 25:71-80. https://doi.org/ 10.1007/s00767-019-00440-z

Mandl GW (2000) The Alpine sector of the Tethyan shelf: examples of Triassic to Jurassic sedimentation and deformation from the Northern Calcareous Alps. Mitteil Österreich Geol Gesell 92:61-70

Nittel P (2006) Beiträge zur Stratigraphie und Mikropaläontologie der Mitteltrias der Innsbrucker Nordkette (Nördliche Kalkalpen, Austria) [Contributions to the stratigraphy and micropaleontology of the middle Triassic of the Innsbrucker Nordkette (Northern Calcareous Alps, Austria)]. Geo.Alp 3:93-145

Pernreiter S (2017) Quartärgeologie und permafrost (Blockgletscher) im Karwendelgebirge SW des Karwendelhauses (Tirol, Österreich) [Quaternary geology and permafrost (rock glaciers) in the Karwendel Mountains SW of the Karwendelhaus (Tyrol, Austria)]. MSc Thesis, University of Innsbruck, Austria, 189 pp

Plan L, Decker K, Faber R, Wagreich M, Grasemann B (2009) Karst morphology and groundwater vulnerability of high alpine karst plateaus. Environ Geol 58:285-297. https://doi.org/10.1007/s00254008-1605-5

Posavec K, Giacopetti M, Materazzi, M, Birk S (2017) Method and Excel VBA Algorithm for Modeling Master Recession Curve UsingTrigonometry Approach, Groundwater (2017), https://doi. org/10.1111/gwat.12549

Plan L, Kuschnig G, Stadler H (2010) Kläffer spring: the major spring of the Vienna water supply (Austria). In: Kresic N, Stevanovic Z (eds) Groundwater hydrology of springs. Elsevier, Amsterdam, pp 411426

Ramspacher P, Zojer H, Froehlich K, Stichler W (1992) The recharge of large springs from a carbonate aquifer near Innsbruck applying environmental tracers. In: Hötzl H, Werner A (eds) Tracer hydrology. Balkema, Rotterdam, The Netherlands, pp 251-257

Reischer M, Bichler B, Spötl C, Höfer-Öllinger G, Wyhlidal S (2015) Karst hydrogeology of the Untersberg Massif and its interaction with the porous aquifer in the adjacent Salzburg Basin. Austr J Earth Sci 108/2:68-81. https://doi.org/10.17738/ajes.2015.0014
Sarnthein M (1966) Sedimentologische Profilreihen aus den mitteltriadischen Karbonatgesteinen der Kalkalpen nördlich und südlich von Innsbruck (sedimentological sections through middle Triassic carbonate rocks of the calcareous Alps north and south of Innsbruck). Berichte Naturwissenschaf-Medizin Vereins Innsbruck 54:33-59

Spötl C (2016) Nordtiroler Kalkalpen (calcareous Alps of North Tyrol). In: Spötl C, Plan L, Christian E (eds) Höhlen und Karst in Österreich [Caves and karst in Austria]. Oberösterreichisches Landesmuseum, Linz, Austria, pp 477-488

Tollmann A (1976) Monographie der Nördlichen Kalkalpen, Teil II: analyse des klassischen nordalpinen Mesozoikums [Monography of the Northern Calcareous Alps, part II: analysis of the north alpine Mesozoic]. Franz Deuticke, Vienna

Viviroli D, Kummu M, Meybeck M et al (2020) increasing dependence of lowland populations on mountain water resources. Nat Sustain 3: 917-928. https://doi.org/10.1038/s41893-020-0559-9

Wagner T, Mayaud C, Benischke R, Birk S (2013) Ein besseres Verständnis des Lurbach-Karstsystems durch ein konzeptionelles Niederschlags-Abfluss-Modell [A better understanding of the Lurbach karst system via a conceptional rainfall-runoff model]. Grundwasser 18:225-235. https://doi.org/10.1007/s00767-0130234-4

Wagner T, Kainz S, Wedenig M, Krainer K, Kellerer-Pirklbauer A, Ribis M, Hergarten S, Winkler G (2019) Wasserwirtschaftliche Aspekte von Blockgletschern in Kristallingebieten der Ostalpen Speicherverhalten, Abflussdynamik und Hydrochemie mit Schwerpunkt Schwermetallbelastungen (RGHeavyMetal) [Water management aspects of rock glaciers in crystalline areas of the eastern Alps: storage, runoff dynamics and hydrochemistry with a focus on heavy metal pollution]. Final report, RGHeavyMetal, 145 pp. https://static.uni-graz.at/fileadmin/_Persoenliche_Webseite/ winkler gerfried/A28165002031 RGHEavyMetal Endbericht barrierefrei.pdf. Accessed September 2021

Wagner T, Pleschberger R, Kainz S, Ribis M, Kellerer-Pirklbauer A, Krainer K, Philippitsch R, Winkler G (2020a) The first consistent inventory of rock glaciers and their hydrological catchments of the Austrian Alps. Austr J Earth Sci 113: 1-23, https://doi.org/10.17738/ ajes.2020.0001

Wagner T, Brodazc A, Krainer K, Winkler G (2020b) Active rock glaciers as shallow groundwater reservoirs, Austrian Alps. Grundwasser 25:215-230. https://doi.org/10.1007/s00767-02000455-X

Winkler G, Wagner T, Pauritsch M, Birk S, Kellerer-Pirklbauer A, Benischke R, Leis A, Morawetz R, Schreilechner MG (2016) Identification and assessment of groundwater flow and storage components of the relict rock glacier Schöneben, Niedere Tauern range, eastern Alps (Austria). Hydrogeol J 24:937-953. https://doi.org/10. 1007/s10040-015-1348-9

Publisher's note Springer Nature remains neutral with regard to jurisdictional claims in published maps and institutional affiliations. 